\title{
Pengaruh Capital Adequacy Ratio dan Non-Performing Loan terhadap Profitabilitas Perusahaan Perbankan
}

\author{
Asriany \\ Universitas Muhammadiyah Palopo \\ asriany@umpalopo.ac.id
}

\begin{abstract}
Abstrak Penelitian ini bertujuan untuk menguji hubungan antara capital adequacy ratio dan non-performing loan terhadap profitabilitas. Populasi dalam penelitian ini adalah perusahaan perbankan yang terdaftar di Bursa Efek Indonesia periode 2015-2019. Teknik purposive sampling digunakan dalam pengambilan sampel dengan jumlah sampel yang diperoleh yakni 15 perusahaan perbankan dengan total obsesrvasi sebanyak 75 observasi. Metode analisis data yang digunakan adalah analisis regresi berganda dengan metode regresi data panel. Hasil pengujian menunjukkan bahwa variabel capital adequacy ratio memiliki hubungan negatif dan tidak signifikan terhadap profitabilitas perusahaan perbankan dan variabel non-performing loan memiliki hubungan negatif dan signfikan terhadap profitabilitas perusahaan perbankan. Nilai Adjusted R-square sebesar 0.207741 yang berarti bahwa variabel capital adequacy ratio dan non-performing loan mampu menjelaskan $20 \%$ variasi variabel profitabilitas dan sisanya $80 \%$ dijelaskan oleh variabel lain yang tidak diteliti.
\end{abstract}

Kata Kunci Capital adequacy ratio, non-performing loan, profitabilitas.

\section{PENDAHULUAN}

Ekonomi Nasional Negara bank memiliki kedudukan yang teramat penting bagi perekonomian dan berfungsi sebagai perantara antara pihak yang memiliki dana lebih dengan pihak yang membutuhkan dana maka bank diharapkan dapat menampung dan meneruskan dana masyarakat secara bertanggung jawab. Bank juga memiliki fungsi sebagai pelaksana kebijakan moneter serta menjaga stabilitas sistem keuangan (Wanindy, 2013). Dikutip dalam Pernyataan Standar Akuntansi Keuangan (PSAK) bahwa "bank merupakan industri yang dalam kegiatan uasahanya mengandalkan kepercayaan masyarakat sehingga tingkat kesehatan bank perlu dijaga". Tingkat kesehatan bank dapat dilihat dalam kegiatan operasionalnya yang mampu berjalan secara normal serta dapat memenuhi kewajiban perusahaannya berdasarkan peraturan mengenai kesehatan perbankan yang ditetapkan bank Indonesia.

Rasio profitabilitas dapat digunakan sebagai indikator untuk mengukur kinerja perbankan, (Hutagalung, 2013). Dalam pengukuran profitabilitas dapat dilakukan dengan menghitung return on asset suatu bank, return on asset merupakan suatu kemampuan perusahaan dalam menghasilkan laba yang bersumber dari jumlah total modal yang dimilikinya. Perhitungan return on asset menggunakan perbandingan antara laba sesudah pajak terhadapa total equitas. yang bersumber dari setoran pemilik modal, laba ditahan dan lainnya sehingga mampu menunjukkan sejauh mana tingkat pengembalian investasi atau modal yang ditanamkan dalam perusahaan (Manurung, 2004). Profitabilitas dapat dipengaruhi beberapa faktor, diantaranya capital adequacy ratio dan non-performing loan yang dapat diteliti dalam pengaruhnya terhadap profitabilitas.

Capital adequacy ratio merupakan rasio kecukupan modal bank yang berkaitan dengan dana yang dihimpun dalam bentuk modal yang dapat digunakan untuk pengukuran kinerja bank. Capital 
adecuacy ratio yang semakin meningkat juga dapat meningkatkan kepercayaan dan keamanan nasabah yang kemudian dapat berdampak positif bagi peningkatan profitabilitas (Fifit, 2013).

Non perfrorming loan atau disebut juga kredit bermasalah merupakan suatu masalah yang dihadapi bank, dimana ketika nasabah tidak mampu membayar hutang yang ditambah bunga sesuai jatuh tempo yang disepakati. Kredit bermasalah yang tinggi dapat menyebabkan pendapatan bank yang akan diterimanya menjadi tertunda yang ditimbulkan dari akibat resiko kredit yang besar, sehingga dapat menyebabkan kerugian cukup besar yang berimbas kepada penurunan profitabilitas. Dari uraian latar belakang diatas, maka penulis mengambil kesimmpulan untuk penelitian dengan judul "Pengaruh Capital Adequacy Ratio (CAR) dan Non-Performing Loan (NPL) Terhadap Profitabilitas Pada Perusahaan Perbankan Yang Terdaftar Di Bursa Efek Indonesia Periode 2015-2019”.

\section{LANDASAN TEORI}

\section{Profitabilitas}

Profitabilitas adalah rasio yang digunakan untuk menilai sebuah kemampuan bank dalam menghasilkan laba dari kegiatan bisnisnya, dimana dalam sebuah perusahaan tentunya memiliki tujuan operasional yakni menghasilkan profit atau keuntungan dalam jangka pendek maupun jangka panjang dengan ditunjang sistem operasional perusahaan yang baik (Marliyanti, 2017).

\section{Capital adequacy ratio}

Capital adequacy ratio merupakan rasio yang mengukur sejauh mana seluruh aktiva memiliki resiko yang dibiayai dari modal sendiri yang dimiliki bank selain dana yang diperoleh dari luar bank seperti dana masyarakat, pinjaman (utang), dan lain sebagainya. Dendawijaya (2009), menyatakan bahwa "capital adequacy ratio adalah indikator untuk mengukur sejauh mana kemampuan bank dalam menutupi setiap penurunan aktivanya akibat kerugian yang dialami bank akibat dari resiko aktiva". Dalam perturan Bank Indonesia nomor 10/15/PBI/2008 tanggal 24 september 2008 standar besarnya capital adequacy ratio yang ditetapkan mengenai kewajiban modal minimum bank pada pasal 2 yakni "bank wajib menyediakan modal minimum sebesar $8 \%$ (delapan persen) dari aset tertimbang menurut resiko (ATMR)".

$$
C A R=\frac{\text { modal bank }}{\begin{array}{c}
\text { aktiva tertimbang } \\
\text { menurut risiko }
\end{array}}
$$

\section{Non -performing loan}

Menurut Riyadi (2006), non-performing loan merupakan rasio yang menunjukkan kemampuan bank dalam mengatur kredit yang mengalami masalah. Bank perlu berhati-hati dalam mendistribusikan kredit sehingga tidak terjadi resiko kredit yang cukup tinggi, setelah penyaluran kredit pihak bank harus melakukan pengawasan terhadap pengalokasian kredit yang diberikan serta loyalitas dan kesanggupan debitur dalam menjalankan kewajibannya (Ali, 2004). Resiko kredit yang semakin tinggi dapat menggambarkan kapasitas kredit yang buruk atau dikatakan terindikasi adanya kredit macet. Akibat dari kredit macet tersebut dapat menghambat keuntungan yang diperoleh dari laba kredit sehingga menyebabkan menurunnya profitabilitas.

$$
N P L=\frac{\text { jumlah kredit bermasalah }}{\text { total kredit }} \times 100 \%
$$

\section{Hipotesis}

Berasarkan penjelasan teoritis diatas, maa diperoleh hipotesis sebagai berikut:

1) Diduga bahwa capital adequacy ratio berpengaruh positif terhadap profitabilitas pada perusahaan perbankan yang terdaftar di Bursa Efek Indonesia periode 2015-2019 
2) Diduga bahwa non-performing loan berpengaruh negatif terhadap profitabilitas pada perusahaan perbankan yang terdaftar di Bursa Efek Indonesia periode 2015-2019.

\section{METODOLOGI PENELITIAN}

Metode analisis data yang digunakan adalah analisis regresi berganda dengan metode regresi data panel. Populasi dalam penelitian ini adalah perusahaan perbankan yang terdaftar di Bursa Efek Indonesia periode 2015-2019. Teknik purposive sampling digunakan dalam pengambilan sampel dengan jumlah sampel yang diperoleh yakni 15 perusahaan perbankan dengan total observasi sebanyak 75 observasi. Kerangka penelitian sebagai berkut:

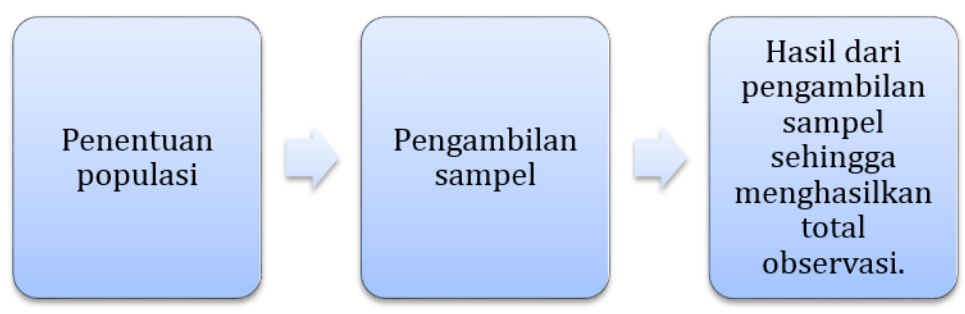

Gambar 1. Kerangka Penelitian

\section{HASIL PENELITIAN}

Menggunakan metode analisis regresi data panel, dengan hasil estimasi uji random Effect Model sebagai estimasi yang tepat dalam penelitian ini.

Tabel. 1. analisis regresi berganda dan uji hipotesis

\begin{tabular}{|c|c|c|c|c|}
\hline Variable & Coefficient & Std. Error & t-Statistic & Prob. \\
\hline $\mathrm{C}$ & 15.48702 & 2.254528 & 6.869296 & 0.0000 \\
\hline CAR & -0.000188 & 0.000746 & -0.251837 & 0.8019 \\
\hline \multirow[t]{3}{*}{ NPL } & -1.520428 & 0.332045 & -4.578980 & 0.0000 \\
\hline & \multicolumn{2}{|c|}{ Effects Specification } & & \\
\hline & & & S.D. & Rho \\
\hline \multicolumn{3}{|l|}{ Cross-section random } & 5.488084 & 0.7529 \\
\hline \multicolumn{3}{|l|}{ Idiosyncratic random } & 3.144387 & 0.2471 \\
\hline \multicolumn{5}{|c|}{ Weighted Statistics } \\
\hline R-squared & 0.229153 & \multicolumn{2}{|c|}{ Mean dependent var } & 2.596227 \\
\hline Adjusted R-squared & 0.207741 & \multicolumn{2}{|c|}{ S.D. dependent var } & 3.551445 \\
\hline S.E. of regression & 3.161103 & \multicolumn{2}{|c|}{ Sum squared resid } & 719.4654 \\
\hline F-statistic & 10.70189 & \multicolumn{2}{|c|}{ Durbin-Watson stat } & 0.904709 \\
\hline Prob(F-statistic) & 0.000085 & & & \\
\hline \multicolumn{5}{|c|}{ Unweighted Statistics } \\
\hline R-squared & 0.238346 & \multicolumn{2}{|c|}{ Mean dependent var } & 10.45973 \\
\hline Sum squared resid & 2921.149 & \multicolumn{2}{|c|}{ Durbin-Watson stat } & 0.222826 \\
\hline
\end{tabular}

Dari uji regresi data panel di atas dapat dilihat koefisen dari setiap varibel dengan persamaan model regresi data panel sebagai berikut:

Profitabilitas $=15.48702-0.000188$ CAR -1.520428 NPL

Berdasarkan persamaan tersebut dapat jelaskan bahwa: 
1) Konstanta sebesar 15.48702 berarti bahwa jika seluruh variabel independen bernilai 0 , profitabilitas tetap sebesar 15.48702

2) Koefisien capital adequacy ratio yakni sebesar - 0.000188 , dimana jika capital adequacy ratio mengalami kenaikan sebesar $1 \%$ dan variabel lain dianggap konstan maka profitabilitas akan mengalami penurunan sebesar 0.000188 .

3) Koefisen non-performing loan yakni sebesar - 1.520428, dimana jika non-performing loan mengalami kenaikan sebesar 1\% dan variabel lain dianggap konstan maka profitabilitas akan mengalami penurunan sebesar 1.520428 .

\section{Uji Hipotesis}

Uji T Parsial

Dengan ketentuan jika nilai probabilitas $>0.05$ dapat diartikan secara parsial variabel independen tidak berpengaruh signifikan, sebaliknya jika probabilitas $<0.05$ maka secara parsial variabel berpengaruh secara parsial.

Tabel 2. Uji T Parsial

\begin{tabular}{|c|r|r|r|c|}
\hline Variable & Coefficient & Std. Error & t-Statistic & Prob. \\
\hline C & 15.48702 & 2.254528 & 6.869296 & 0.0000 \\
\hline CAR & -0.000188 & 0.000746 & -0.251837 & 0.8019 \\
\hline NPL & -1.520428 & 0.332045 & -4.578980 & 0.0000 \\
\hline
\end{tabular}

1) Berdasarkan hasil uji diketahui nilai probabilitas capital adequacy ratio yaitu 0.8019 $(0.8019>0.05)$. Hal ini berarti bahwa secara parsial capital adequacy ratio tidak berpengaruh signifikan terhadap profitabilitas serta memiliki arah hubungan negatif yang dilihat dari nilai koefisien capital adequacy ratio yakni -0.000188.

Hipotesis capital adequacy ratio berpengaruh positif terhadap profitabilitas, ditolak.

2) Berdasarkan hasil uji diketahui nilai probabilitas non-performing loan yaitu 0.0000 $(0.0000<0.05)$. Hal ini berarti bahwa secara parsial non-performing loan berpengaruh signifikan terhadap profitabilitas memiliki arah hubungan negatif yang dilihat dari nilai koefisien nonperforming loan yakni -1.520428.

Hipotesis non-performing loan berpengaruh negatif terhadap profitabilitas, diterima.

\section{Uji F Simultan dan Koefisen Determinasi}

Jika probabilitas < 0.05 maka secara simultan variabel berpengaruh secara bersama-sama. Sehingga dapat dijelaskan bahwa:

Secara simultan variabel capital adequacy ratio dan non-performing loan berpengaruh signifikan terhadap variabel profitabilitas Berdasarkan hasil uji random effect model diketahui nilai Adjusted $R$-square sebesar 0.207741 yang berarti bahwa variabel capital adequacy ratio dan non-performing loan mampu menjelaskan $20 \%$ variasi variabel profitabilitas dan sisanya $80 \%$ dijelaskan oleh variabel lain yang tidak diteliti.

\section{PEMBAHASAN}

1) Secara parsial capital adequacy ratio tidak berpengaruh signifikan terhadap profitabilitas serta memiliki arah hubungan negatif yang dilihat dari nilai koefisien capital adequacy ratio yakni -0.000188 . Hal ini dikarenakan dimana capital adequacy ratio yang tinggi dapat mengurangi kemampuan bank dalam melakukan ekspansi usahanya karena semakin besarnya cadangan modal yang digunakan untuk menutupi risiko kerugian. Pertumbuhan modal yang tinggi tidak dapat mengimbangi pertumbuhan aktiva produktif, sehingga akan berdampak pada kemampuan bank untuk memperluas penyaluran dananya. Hal inilah yang 
diduga menjadi penyebab capital adequancy ratio berpengaruh negatif tidak signifikan terhadap Profitabilitas

2) Secara parsial non-performing loan berpengaruh signifikan terhadap profitabilitas memiliki arah hubungan negatif yang dilihat dari nilai koefisien non- performing loan yakni 1.520428. Hal ini bisa terjadi karena semua kredit memiliki risiko tinggi, besarnya pemberian kredit tidak didukung dengan kualitas kredit, kualitas kredit yang buruk karena kurangnya pengendalian atas kredit, debitur gagal atau mengalami masalah dalam memenuhi kewajibannya sesuai yang ditetapkan oleh pihak Bank. Hal ini dapat meningkatkan risiko terjadinya kredit bermasalah sehingga dapat menurunkan kemampuan likuiditas bank serta memungkinkan dapat menurunkan pendapatan bank.

\section{KESIMPULAN}

Berdasarkan atas hasil penelitian dan penjelasan sebelumnya, maka dapat ditarik kesimpulan sebagai berikut:

Hasil pengujian dalam penelitian ini menunjukkan bahwa capital adequacy ratio tidak berpengaruh signifikan terhadap profitabilitas pada perusahaan perbankan yang terdaftar di Bursa Efek Indonesia periode 2015-2019. Hasil pengujian dalam penelitian ini menunjukkan bahwa bahwa non-performing loan berpengaruh negatif dan signifikan terhadap profitabilitas pada perusahaan perbankan yang terdaftar di Bursa Efek Indonesia periode 2015-2019.

\section{Saran}

Dari penelitian dan pembahasan yang dilakukan maka peneliti memberikan saran sebagai berikut:

1. Bagi perusahaan

a. Perusahaan perbankan dapat menggunakan seluruh variabel dalam penelitian ini sebagai pertimbangan untuk meningkatkan profitabilitas.

2. Bagi peneliti selanjutnya

a. Untuk peneliti selanjutnya diharapkan menambah variabel yang lebih lengkap lagi

b. Peneliti selanjutnya dapat menggunakan perusahaan yang berbeda dan memperpanjang tahun penelitian sehingga penelitian selanjutnya dapat menjelaskan profitabilitas dengan sempurna.

\section{UCAPAN TERIMA KASIH}

Ucapan terima kasih kepada Rektor Universitas Muhammadiyah Palopo, Lembaga Penelitian dan Pengabdian Kepada Masyarakat (LPPM), serta seluruh rekan-rekan dosen yang telah membantu dalam penelitian ini baik dalam bantuan fasilitas, dana maupun peralatan sehingga penelitian ini dapat berjalan.

\section{DAFTAR PUSTAKA}

Ali, M. 2004. Asset Liability Management (menyiasati risiko pasar dan risiko operasional dalam perbankan). Elex Media Komputindo. Jakarta.

Dendawijaya, Lukman. 2009. Manajemen perbankan. Ghalia Indonesia. Jakarta.

Fifit Syaiful Putri, 2013, Pengaruh Risiko Kredit dan Tingkat Kecukupan Modal terhadap Tingkat Profitabilitas pada Perusahaan Perbankan yang Terdaftar di Bursa Efek Indonesia, Jurnal Ekonomi da Bisnis Universitas Negeri Padang.

Hutagalung, Esther Novelina, Djumahir \& Kusuma Ratnawati. 2013. "Analisa Rasio Keuangaan terhadap kinerja Bank Umum di Indonesia", Jurnal Aplikasi Manajemen, Vol.II, No.1, Maret 2013, ISSN: 1693-5241.

Marliyanti V, 2017. "PENGARUH CAPITAL ADEQUACY RATIO (CAR), NONPERFORMING LOAN (NPL), LIKUIDITAS DAN EFISIENSI OPERASIONAL 
TERHADAP PROFITABILITAS PERUSAHAAN PERBANKAN". Ekonomi Manajemen. Universitas Muhammadiyah Purwekerto.

Prathama Rahardja dan Mandala Manurung, Teori Ekonomi Makro, Fakultas Ekonomi Universitas Indonesia, 2004.

Riyadi, S. 2006. Banking Assets and Liability management. Edisi Ketiga. FE UI. Jakarta.

Wanindy, Pamela. 2013. Pengaruh Capital Adequacy Ratio (CAR) terhadap prifitabilitas. Journal. Semarang: UNDIP. 